\title{
Chronic Pain and Pharmacotherapy in Chronic Renal Patients on Hemodialysis
}

\author{
Olvani Martins da Silva1,2, Bruna Bautitz², Fanierli Benedeti², Ligyani Pauly², \\ Eneida Rejane Rabelo-Silva ${ }^{1}$ \\ ${ }^{1}$ Graduate Programa at Federal University of Rio Grande do Sul, Porto Alegre, Brazil \\ ${ }^{2}$ Santa Catarina State University, Chapecó, Brazil \\ Email:olvanims@hotmail.com, brunabautitz@gmail.com,fani_benedetti@outlook.com, ligi_pauly@hotmail.com, \\ eneidarabelo@gmail.com
}

How to cite this paper: da Silva, O.M., Bautitz, B., Benedeti, F., Pauly, L. and Rabelo-Silva, E.R. (2016) Chronic Pain and Pharmacotherapy in Chronic Renal Patients on Hemodialysis. Open Journal of Nursing, 6, 741-750.

http://dx.doi.org/10.4236/ojn.2016.69075

Received: August 17, 2016

Accepted: September 16, 2016

Published: September 19, 2016

Copyright $\odot 2016$ by authors and Scientific Research Publishing Inc. This work is licensed under the Creative Commons Attribution International License (CC BY 4.0).

http://creativecommons.org/licenses/by/4.0/

\begin{abstract}
Objective: To analyze the intensity of chronic pain and pharmacotherapy in chronic renal patients on hemodialysis. Method: This is a cross-sectional, prospective study conducted in a Service of Substitute Renal Therapy in the South region of Brazil. Seventy adult patients with chronic renal disease, who were undergoing hemodialysis treatment in the first half of 2015, participated in the study. We used the Graduated Scale for Chronic Pain. The data were analyzed with the Statistical Package for Social Sciences software version 18.0. The study was approved under $\mathrm{N}^{\circ}$. CAAE: 20138913.4.0000.0118. Results: Fifty-one (72\%) patients reported some forms of pain in the last six months, 17 (24\%) reported severely limiting pain, high interference and persistence. Painkillers were most widely used therapy for pain management, in 19 patients (27\%). Conclusion: Chronic pain was reported in different degrees of intensity, with severely limiting character, high interference, and persistence. Painkillers were the most widely used pharmacological class to control it.
\end{abstract}

\section{Keywords}

Hemodialysis, Chronic Pain, Pain Management

\section{Introduction}

Chronic pain is one of the most common symptoms reported by chronic renal patients. This pain is complex and its management is a challenge for health professionals, primarily by its individual character and manifestations that vary among individuals [1]. In a sample involving 591 participants, pain was perceived by $72.4 \%$ of patients, being described as of moderate or severe intensity by $46.5 \%$ [2]. Similar results were demonstrated in a study conducted by Masajtis-Zagajewska et al. [3] 
Studies [1] [4] indicate that chronic pain is referred by chronic renal patients with varying intensity, which induces the use of analgesics and consequent polypharmacy. The presence of pain brings as a consequence the reduction of physical function [5], changes in the sleep pattern [6] [7], depressive symptoms, and hindering of the quality of life [8] [9]. Despite these limitations, it is a little valued symptom, in detriment to other priorities related to treatment [10], or under notified due to recognition and appropriate management barriers such as time limitations for assessing the patient, unavailability of evaluation instruments, lack of experience on the part of the professional, or belief that chronic pain is more difficult to be evaluated and handled [11].

Some studies [10] [12] [13] demonstrated concern regarding the pain of chronic renal patients in hemodialysis to provide better management of care as well as by the need to implement more effective treatments to achieve relief [14].

The use of pharmacotherapy continues to be a positive element in the treatment of pain, even with limited evidence regarding the pharmacology of some medications for this population. On the other hand, non-pharmacological management strategies based on evidence for the management of pain have been described especially for pain of musculoskeletal origin [11].

The identification and evaluation of pain intensity by means of validated scales allow the implementation of routines in pain management and contribute to the relationship between professionals and patients [1]. However, studies that investigate the presence of pain and its management in chronic renal patients in hemodialysis by using validated scales are incipient in Latin American centers.

In this perspective, this study was conducted to analyze chronic pain in chronic renal patients in hemodialysis and pharmacotherapy used by patients. This study becomes relevant for aiding health professionals on planning for the evaluation and control of the pain of patients in this condition.

\section{Methods}

\subsection{Type of Study}

This is a transversal and prospective study performed in a service specialized in caring for patients with chronic renal diseases in all types of renal substitution therapy in the southern region of Brazil.

\subsection{Sample and Participants}

The participants were adult patients with chronic renal disease undergoing hemodialysis treatment. We included patients regardless of period of early treatment and excluding those with co-morbidities that might confuse pain not caused by renal disease and its complications.

For the estimation of the sample, a prevalence of 27 (77\%) was considered, as described in a study [4] carried out with chronic renal patients in hemodialysis treatment that referred pain daily. The sample size of the study was calculated to be 70 individuals of the 150 patients being cared for in the unit. We assumed the same percentage of 
pain, considering a sampling error of $6 \%$, and a confidence level of $90 \%$.

\subsection{Data Collection and Instrument}

Data collection occurred in the first half of 2015, during the hemodialysis session by previously trained researchers. We used an instrument with sociodemographic and clinical variables to characterize the sample. To evaluate the pain, the graduated scale for chronic pain * was adopted, adapted, and validated for Brazil [15]. This scale is made up of eight items that assess the frequency, intensity, and disability linked to pain. The questions are reminders, concerning the presence of pain in the last six months. From question two (02) to eight (08), the questions aid the individual to remember the pain of the past three months, marking on a Likert scale of 10 points [15].

The classification of chronic pain in degrees is determined by calculating the scores from the Likert scale, in which zero is without pain, I low pain intensity, II high pain intensity, III moderately limiting pain, and IV severely limiting pain. Once the degree is established, it is possible to check the interference of pain, which can be described as low interference (grade I and II) and high interference (grade III and IV). Persistence of pain is established for the days in which the patient presented pain, being low persistence between 1 and 87 days and persistent between 90 and 180 days [15].

\subsection{Data Analysis}

The data was tabulated and processed in the Statistical Package for Social Science (SPSS) program, version 18.0, and analyzed through descriptive statistics so that continuous variables were expressed as mean values and standard deviation, and categorical with absolute and relative frequencies.

The study was carried out according to the ethical and legal premises provided for in Resolution 466/2012, which regulates research on humans in Brazil. It was approved by the Ethics Committee of the State University of Santa Catarina, under opinion no. 453,508 on $11 / 8 / 2013$, CAAE 20138913.4.0000.0118. The patients agreed to participate by signing an informed consent form in two copies.

\section{Results}

\subsection{Characteristics of the Sample}

The sample was composed of 70 patients, 37 (53\%) male with mean age of $58 \pm 16$ years old. The median time of treatment was of $3(1-6.5)$ years old. Among the patients, 51 (72\%) reported having felt some kind of pain in the last six months. The most affected site was the lower limbs in 20 (28\%) patients, followed by column in $17(24 \%)$, and in smaller percentages pain in other regions of the body. These characteristics are shown in Table 1.

\subsection{Classification of Chronic Pain Regarding Intensity, Interference, and Persistence}

Of the patients who reported pain, the intensity was referred to as severely limiting by 
Table 1. Distribution of patients in hemodialysis according to treatment time and site of pain.

\begin{tabular}{cc}
\hline Variables & $\mathbf{n}=70$ \\
\hline Age (years old) & $58 \pm 16$ \\
Sex (male) & $37(53 \%)$ \\
Treatment time (years) ${ }^{*}$ & $3(1-6.5)$ \\
Presence of pain in the last 6 months & $51(72 \%)$ \\
Site of pain & \\
Lower limbs & $20(28 \%)$ \\
Back (lumbar, spine) & $17(24 \%)$ \\
Headache & $4(6 \%)$ \\
Other sites & $10(14 \%)$ \\
\hline
\end{tabular}

${ }^{\star}$ Continuous variables are expressed as mean \pm standard deviation, median and interquartile interval; $\mathrm{n}=70$.

$17(24 \%)$, moderately limiting by 13 (19\%), and of high intensity pain by 11 patients (16\%). Regarding interference, high interference was reported by 31 patients (44\%) and low interference by 13 (19\%). As for persistence of the pain, 29 patients (41\%) complain of long persistence. The data are presented in Table 2.

\subsection{Pharmacotherapy Used by Chronic Renal Patients in Hemodialysis Treatment}

Of the patients who reported pain, 35 (50\%) use pharmacotherapy for treatment and relief. Analgesics were presented as elective medicines for pain management in 19 (27\%) patients. Other medicines appeared in smaller proportion, and $12(17 \%)$ patients used other non-nominated medicines (Table 3).

\section{Discussion}

This is one of the few studies that examined the presence of chronic pain and therapy used in chronic renal patients undergoing hemodialysis. The results indicated that over $70 \%$ of the studied patients presented pain in the six months prior to the study. Of those patients, more than half showed moderate to severe pain intensity, and used analgesics to relief.

A study that evaluated 164 patients in hemodialysis and compared the prevalence of pain, their locations, features and use of analgesics, evidenced that $54 \%$ of patients presented pain in more than one location [3]. In addition, approximately $35 \%$ of the complaints during the hemodialysis session are related to recurrent or constant pain, many of physiopathological origin, which can be diagnosed and treated, as muscle pain from cramps and musculoskeletal pain, caused by bone dystrophy [15].

Musculoskeletal pain is one of the most common symptoms of chronic pain in patients with terminal renal failure [16] [17]. In this study, pain was reported by 20 (28\%) patients in the lower limbs, and by 17 (24\%) associated with the back (lumbar and spine). Similar results were found in studies [3] [18] in which the location of greatest 
Table 2. Classification of chronic pain regarding intensity, interference, and persistence.

\begin{tabular}{cc}
\hline Degree of intensity & $\mathrm{n}(\%)$ \\
\hline Degree IV: severely limiting pain & $17(24 \%)$ \\
Degree III: moderately limiting pain & $13(19 \%)$ \\
Degree II: high intensity pain & $11(16 \%)$ \\
Degree I: low intensity pain & $03(4 \%)$ \\
Without pain & $19(27 \%)$ \\
Interference of the pain & \\
High interference pain & $31(44 \%)$ \\
Low interference pain & $13(19 \%)$ \\
Without pain & $19(27 \%)$ \\
Persistence of the pain & \\
Persistent pain & $17(24 \%)$ \\
Non-persistent pain & $19(27 \%)$ \\
Without pain &
\end{tabular}

Table 3. Pharmacotherapy used by chronic renal patients in hemodialysis.

\begin{tabular}{cc}
\hline Variables & $\mathbf{n}(\%)$ \\
\hline $\begin{array}{c}\text { Pharmacotherapy used } \\
\text { Presents pain and uses medication } \\
\text { Presents pain and does not use medication } \\
\text { Pharmacological class } \\
\text { Analgesic }\end{array}$ & $35(50 \%)$ \\
Nonsteroidal analgesic and anti-inflammatory & $09(13 \%)$ \\
Benzodiazepines & $19(27 \%)$ \\
Was not able to inform & $02(3 \%)$ \\
\hline
\end{tabular}

frequency was in the lower limbs, followed by the lumbar region. Authors speculate that pain in these areas can be associated with the positioning of the patient, who remains in the same position for hours, causing discomfort, in addition to corroborate to vascular complications in the lower limbs [3] [19].

Changes in the structure and function of the muscles may be manifested by atrophy, weakness of the lower limbs, impaired ambulation, and cramps [20]. Even though it is known that bone alterations may induce diffuse and constant pain, affect lower limbs and the spine, and even compromise an individual's mobility [14].

Recently, a cross-sectional study investigated 456 patients with chronic renal disease for the presence of chronic musculoskeletal pain and its associated factors. The results showed that slightly more than half of the sample presented chronic musculoskeletal pain, and this was significantly and independently associated with hyperuricemia and high levels of calcium and phosphorus [16]. This study did not seek to identify the association of pain with laboratory results, unlike the study by Hsu et al. [16], which 
point out that patients in end-stage renal disease suffered from more severe chronic pain compared to other stages of the disease, possibly due to co-morbidities generated by hyperuricemia, in addition to calcium-phosphorus imbalance [16].

Another cause of bone pain can be attributed to the long time of hemodialysis treatment depending on the deposition of amyloid and beta2-microglobulin [14] [21] and the high levels of parathyroid hormone (PTH) agents of bone resorption [22].

Severe pain was also observed by Masajtis-Zagajewska et al. [3], who observed that, among patients in HD, 55\% described the pain as intense, and $40 \%$ as moderate. In this study, most patients reported severely limiting pain, of high interference and persistence. In the United States, Barakzoy and Moss found pain classified as serious by 34 (76\%) patients [23]. In Europe, 61 (75\%) patients, of a sample of 123 chronic renal patients, reported that the pain completely or partially limited their daily activities, such as cleaning, shopping, and cooking [10].

Pain interferes potentially at work, domestic activities, ability to walk and perform physical activities, sleep and rest, in the mood and satisfaction with life, in addition to harming interpersonal relationships [13].

A Brazilian study noted that pain interferes fully in professional and domestic activities (57.14\%), ability to walk (53.57\%), sleep and rest (46.43\%), mood (39.29\%), satisfaction with life $(32.14 \%)$, and interpersonal relationship (25\%) [4], activities considered common in the daily life of people who are suffering interference, an limitation by the presence of pain, often inducing the use of some kind of analgesia.

Although the prescription of analgesics is recommended, it should be employed only after clinical examination and proper evaluation of pain intensity measured by scale of pain intensity, as advocated by the World Health Organization [24].

Corroborating with this statement, a prospective cohort evaluated the effectiveness of the use of the analgesic scale of WHO to treat pain in patients with terminal renal disease. A sample of 45 patients in hemodialysis was assessed for the type and severity of pain using Short-Form McGill Pain Questionnaire, and later received drug treatment for pain, in accordance with the scale of WHO, for four weeks. At the end of this period, pain relief was observed in $96 \%$ of patients, proving the effectiveness of the scale [23].

In this study, pharmacotherapy used for pain relief was pointed out by $35(50 \%)$ patients who reported chronic pain, and the most used drug classes were analgesics (19 $(27 \%))$, followed by the association of analgesics with non-steroidal anti-inflammatory and benzodiazepines.

A higher percentage for the use of medication was found by Dallaroza et al. [25], in which $86(80.4 \%)$ individuals with chronic pain reported using them, being that $54 \%$ used simple analgesics, especially dipyrone or acetaminophen, and $38.2 \%$ used anti-inflammatory drugs. Benzodiazepines appeared in a lower proportion [25].

Dipyrone is the most employed analgesic for patients with chronic renal disease, for its clinical efficacy, low cost, wide availability, and safety margin for renal patients. Non-steroidal anti-inflammatory drugs (NSAIDS), in their turn, have potential risks of 
bleeding in uremic patients, fluid retention, increased blood pressure, and reduction in glomerular filtration rate (GFR) [17].

In the study by Gamondi et al. (2013) [10], the use of NSAIDS or similar agents predominated in 65(80\%) patients. Hsu et al. [16] did not observe any difference regarding the use of NSAIDS or Chinese herbal medication among patients with hyperuricemia and without hyperuricemia. The explanation found for this condition was the fact that patients were usually recommended to avoid the use of NSAID drugs to protect their renal function [16].

In this perspective, some authors have investigated non-pharmacological techniques for the treatment of pain of chronic renal patients, to avoid side effects of pharmacotherapy [19] [26]. Techniques such as meditation, biofeedback, breathing exercises, hypnosis, yoga, spiritual counseling, cognitive behavioral therapy and psychological therapy can help as alternative treatments for the management of pain [27].

Recently, a study pointed out an alternative method to treat and control chronic pain in patients on hemodialysis, to evaluate the effectiveness of the Tuiná massage therapy in the treatment of pain in the lower limbs of chronic renal patients in hemodialysis, in which 125 patients were divided randomly into: control group $(n=63)$, which received treatment with analgesics for pain relief; and intervention group $(n=62)$, which received the massage. The pain was measured by the analog visual scale. The authors concluded that the use of Tuiná massage was effective in the treatment of pain, since from the 62 patients undergoing the intervention, 56 reported no pain at the end of the study [19].

The Tuiná massage is part of alternative therapies, based on the vitalist paradigm that emphasizes the general state of the patient, not the disease, to interpret it as internal imbalance and not only as a consequence of the invasion of pathogens. Alternative therapies are called complementary health practices, are legitimized, and inserted in the public health system [28], although little widespread and rarely used in healthcare practice for the treatment of chronic pain in patients on hemodialysis.

The relaxation technique was also pointed out as an ally for pain control, through a controlled trial that examined the effects of Benson's relaxation technique on the intensity of pain and quality of life in chronic renal patients. In total, 81 completed the segment (41 patients in the intervention group and 40 in the control group). Patients in the intervention group were instructed to listen to an audio tape of the relaxation technique twice a day for 20 minutes, for eight weeks [29].

Pain and quality of life were assessed through scales at the beginning and at the end of the intervention. The results showed efficacy for the relief of pain intensity in patients undergoing hemodialysis over time, and it also improved quality of life [29].

Other non-pharmacological technique was conducted through a quasi-experimental study in a sample of 79 patients with chronic pain of different etiologies, to assess the impact of a psychoeducational program of eight weeks in pain intensity, disability and depressive symptoms of patients with chronic pain. The assessment was performed through cognitive behavioral approach, which in the end proved effective for the con- 
trol of chronic pain by reducing significantly the scores of pain intensity, disability related to depressive symptoms and pain in the studied sample [26].

\subsection{Clinical Implications of the Study}

The implications of this study for the practice is to serve as an alert to the stress that the recognition of chronic pain in chronic renal patient on hemodialysis by the health team can help in improving the treatment and quality of life of the patient.

The use of pharmacotherapy, although it produces an instant effect in reducing or controlling the pain, brings undesirable side effects, therefore the use of non-pharmacological techniques may be a safe low risk alternative and that makes possible to reduce the intensity of the pain. Clinical studies using non-pharmacological therapies must be explored.

\subsection{Study Limitations}

The inclusion of laboratory tests such as calcium and phosphorus was not part of the objective of this study and, therefore, was not collected. This prevented the association of these variables with the presence of pain.

\section{Conclusion}

Chronic pain was present in many of the chronic renal patients undergoing hemodialysis. When present, its nature was severely limiting, of high interference, and persistent. Analgesics were the most widely used pharmacological class to control pain.

\section{Acknowledgements}

The authors acknowledge Dr. Michael Von Korff, lead author of the graded chronic pain scale and Dr. Eduardo Sawaya Botelho Bracher that validated the scale to the Brazilian context.

\section{References}

[1] Marques, V.R., Benetti, P.E., Benetti, E.R.R., Rosanelli, C.L.S.P., Colet, C.F. and Stumm, E.M.F. (2016) Pain Intensity Assessment in Chronic Renal Patients on Hemodialysis. ReV Dor, 17, 96-100. http://dx.doi.org/10.5935/1806-0013.20160023

[2] Davison, S.N. and Jhangri, G.S. (2010) Impact of Pain and Symptom Burden on the Health-Related Quality of Life of Hemodialysis Patients. Journal of Pain and Symptom Management, 39, 477-485. http://dx.doi.org/10.1016/j.jpainsymman.2009.08.008

[3] Masajtis-Zagajewska, A. (2011) Similar Prevalence but Different Characteristics of Pain in Kidney Transplant Recipients and Chronic Hemodialysis Patients. Clinical Transplantation, 25, 144-151. http://dx.doi.org/10.1111/j.1399-0012.2010.01359.x

[4] Silva, F.S., Pinheiro, M.S.F., França, R.C., Mendonça, A.E.O., Simpson, C.A. and Leite, E.M.D. (2013) Avaliação da dor óssea em pacientes renais crônicos com distúrbio mineral. Rev enferm UFPE on line, 7, 1406-1411. http://www.revista.ufpe.br/revistaenfermagem/index.php/revista/article/view/4381

[5] Wu, J., Ginsberg, J.S., Zhan, M., Diamantidis, C.J., Chen, J., Woods, C. and Fink, J.C. (2015) 
Chronic Pain and Analgesic Use in CKD: Implications for Patient Safety. Clinical Journal of the American Society of Nephrology, 10, 435-442. http://dx.doi.org/10.2215/CJN.06520714

[6] Unruh, M.L. and Cohen, L.M. (2012) Sleep and Pain Management Are Key Components of Patient Care in ESRD. Nephrology Dialysis Transplantation, 27, 2618-2620.

http://dx.doi.org/10.1093/ndt/gfs165

[7] Harris, T.J., et al. (2012) Pain, Sleep Disturbance and Survival in Hemodialysis Patients. Nephrology Dialysis Transplantation, 27, 758-765. http://dx.doi.org/10.1093/ndt/gfr355

[8] Belayev, L.Y., et al. (2015) Longitudinal Associations of Depressive Symptoms and Pain with Quality of Life in Patients Receiving Chronic Hemodialysis. Hemodialysis International, 19, 216-224. http://dx.doi.org/10.1111/hdi.12247

[9] Skaer, T.L. (2015) Research Findings Using Mindfulness-Based Interventions for Chronic Pain. Pain Studies and Treatment, 3, 38-45. http://dx.doi.org/10.4236/pst.2015.34005

[10] Gamondi, C., et al. (2013) Frequency and Severity of Pain and Symptom Distress among Patients with Chronic Kidney Disease Receiving Dialysis. Swiss Medical Weekly, 143, w13750. http://www.ncbi.nlm.nih.gov/pubmed/23443906

[11] Koncicki, H.M., Brennan, F., Vinen, K. and Davison, S.N. (2015) An Approach to Pain Management in End Stage Renal Disease: Considerations for General Management and Intradialytic Symptoms. Seminars in Dialysis, 28, 384-391.

http://dx.doi.org/10.1111/sdi.12372

[12] Weisbord, S.D. (2013) Comparison of Symptom Management Strategies for Pain, Erectile Dysfunction, and Depression in Patients Receiving Chronic Hemodialysis: A Cluster Randomized Effectiveness Trial. Clinical Journal of the American Society of Nephrology, 8, 90-99. http://dx.doi.org/10.2215/CJN.04450512

[13] Silva, F.S., Silva, S.Y.B., Pinheiro, M.G.C., Pinheiro, M.S.F., França, R.C. and Simpson, C.A. (2014) Palliative Care for Pain Originated from the Bone Mineral Disease of Chronic Renal Failure. Journal of Research: Fundamental Care Online, 6, 767-775. http://dx.doi.org/10.9789/2175-5361.2014v6n2p767 http://www.seer.unirio.br/index.php/cuidadofundamental/article/view/3163

[14] Silva, Lúcio; Mendonça, Alexandre Tourino; Carvalho, Lilian de Almeida. (2013) As características da dor em portadores de insuficiência renal crônica em programa de hemodiálise. Revista da Universidade Vale do Rio Verde, Três Corações, 10, 590-599.

[15] Bracher, E.S.B. (2008) Adaptação e validação da versão em português da escaa graduada de dor crônica para o contexto cultural brasileiro. Tese Doutorado, Faculdade de Medicina de São Paulo.

[16] Hsu, H.J., et al. (2014) Factors Associated with Chronic Musculoskeletal Pain in Patients with Chronic Kidney Disease. BMC Nephrology, 15, 6.

http://dx.doi.org/10.1186/1471-2369-15-6 http://bmcnephrol.biomedcentral.com/articles/10.1186/1471-2369-15-6

[17] Sakata, R.K. and Nunes, M.H. (2014) Analgesics use for Kidney Failure. Revista Dor, 15, 224-229. http://dx.doi.org/10.5935/1806-0013.20140048

[18] Pereira, L.V., et al. (2014) Prevalência, intensidade de dor crônica e autopercepção de saúde entre idosos: estudo de base populacional. Revista Latino-Americana de Enfermagem, 22, 662-669. http://dx.doi.org/10.1590/0104-1169.3591.2465

[19] Labrada, Y.L., Rojas, S.M.T., Santisteban, E.G. and Ríos, M.R.M. (2013) Efectividad del masaje tuina como tratamiento para el alivio de dolor a pacientes sometidos a hemodiálisis. Multimed, 17, 3. http://saudepublica.bvs.br/pesquisa/resource/pt/cum-56818

[20] Corrêa, L.B., Oliveira, R.N., Cantareli, F. and Cunha, L.S. (2009) Efeito do Treinamento 
Muscular Periférico na Capacidade Funcional e Qualidade de Vida nos Pacientes em Hemodiálise. Jornal Brasileiro de Nefrologia, 31, 18-24.

http://www.jbn.org.br/details/5/en-US/effect-of-peripheral-muscle-training-on-functionalcapacity-and-quality-of-life-in-patients-on-hemodialysis

[21] Planas, H.J., Pereira, L.L.C., Almirola, M.H., Ramos, M.G. and Inastría, E. (2014) Amiloidosis asociada a la hemodiálises. Revista Cubana de Medicina, 53, 478-482.

[22] Mosca, L.M., et al. (2013) Dor óssea no hiperparatireoidismo secundário: impacto inicial da paratireoidectomia. Revista Brasileira de Cirurgia de Cabeça e Pescoço, 42, 190-193.

[23] Barakzoy, A.S. and Alvin, H. (2006) Efficacy of the World Health Organization Analgesic Ladder to Treat Pain in End-Stage Renal Disease. Journal of the American Society of Nephrology, 17, 3198-3203. http://dx.doi.org/10.1681/ASN.2006050477

[24] Vargas-Schaffer, G. (2010) Is the WHO Analgesic Ladder Still Valid? Twenty-Four Years of Experience. Canadian Family Physician, 56, 514-517.

[25] Dellaroza, M.S.G., et al. (2008) Caracterização da dor crônica e métodos analgésicos utilizados por idosos na comunidade. Revista da Associação Médica Brasileira, 54, 36-41. http://dx.doi.org/10.1590/S0104-42302008000100018

[26] Salvetti, M.G., Cobelo, A., Vernalha, P.M., Vianna, C.I.A., Canarezi, L.C.C.C. and Calegare, R.G.L. (2012) Efeitos de um programa psicoeducativo no controle da dor crônica. Revista Latino-Americana de Enfermagem, 20, 896-902. http://dx.doi.org/10.1590/S0104-11692012000500011

[27] Santoro, D., Satta, E., Messina, S., Costantino, G., Savica, V. and Bellinghieri, G. (2012) Pain in End-Stage Renal Disease: A Frequent and Neglected Clinical Problem. Clinical Nephrology, 79 , 2-11. http://dx.doi.org/10.5414/cnx77s104

[28] Cintra, M.E.R. and Pereira, P.P.G. (2012) Percepções de Corpo Identificadas entre Pacientes e Profissionais de Medicina Tradicional Chinesa do Centro de Saúde Escola do Butantã. Saúde e Sociedade, 21, 193-205. http://dx.doi.org/10.1590/S0104-12902012000100019

[29] Rambod, M., Sharif, F., Pourali-Mohammadi, N., Pasyar, N. and Rafii, F. (2014) Evaluation of the Effect of Benson's Relaxation Technique on Pain and Quality of Life of Haemodialysis Patients: A Randomized Controlled Trial. International Journal of Nursing Studies, 51, 964-973. http://dx.doi.org/10.1016/j.ijnurstu.2013.11.004

\section{Submit or recommend next manuscript to SCIRP and we will provide best service for you:}

Accepting pre-submission inquiries through Email, Facebook, LinkedIn, Twitter, etc.

A wide selection of journals (inclusive of 9 subjects, more than 200 journals)

Providing 24-hour high-quality service

User-friendly online submission system

Fair and swift peer-review system

Efficient typesetting and proofreading procedure

Display of the result of downloads and visits, as well as the number of cited articles

Maximum dissemination of your research work

Submit your manuscript at: http://papersubmission.scirp.org/

Or contact ojn@scirp.org 